2005

\title{
Rewrite Copyright: Protecting Creativity and Social Utility in the Digital Age
}

Richard H. Chused

New York Law School, richard.chused@nyls.edu

Follow this and additional works at: http://digitalcommons.nyls.edu/fac_articles_chapters

\section{Recommended Citation}

38 Isr. L. Rev. 80 (2005)

This Article is brought to you for free and open access by the Faculty Scholarship at DigitalCommons@NYLS. It has been accepted for inclusion in Articles \& Chapters by an authorized administrator of DigitalCommons@NYLS. 


\title{
REWRITE COPYRIGHT: PROTECTING CREATIVITY AND SOCIAL UTILITY IN THE DIGITAL AGE
}

\author{
Richard H. Chused"
}

\begin{abstract}
Debate about the impact of modern technology on copyright law has become polarizedeven harsh. Owners, with some justification, contend that copying has become too easy and that strong protections for their assets must be implemented in order to insure the continued production of creative work. Users respond, with some justification, that such strong protections place intolerable constraints on their rights to browse in digital space, of contemporary culture and fairly use copyright works. The form of the debate-with both sides raising valid problems and neither finding an easy solution inside the existing structure of copyright law-suggests a need to rewrite copyright to insure remuneration to copyright owners while still providing easy, cheap access for users.

The most viable method for achieving such a goal is to institute a wide ranging system of levies on all devices and media that make it possible to quickly and easily copy protected copyright subject matter. In return for the payment of levies, owners would be required to allow users undisturbed access to their copyrighted works. This paper uses the sometimes checkered history of American copyright law as a vehicle for discussion of the problems technology presents to contemporary intellectual property law, the need for a levy system, the most significant requirements of a levy system and the nature of objections likely to arise to use of such a system.
\end{abstract}

\section{Introduction}

Tens of millions of pages of printed copyrighted materials are copied by machine every year at American universities and other institutions. Many of the copies, of

- Professor of Law, Georgetown University Law Center. Fulbright Scholar and Visiting Lecturer, Law Faculty, Hebrew University of Jerusalem, 2004-2005.

I am very grateful to the Fulbright Program for supporting my desire to teach and learn in Israel, and to Hebrew University for allowing me to visit and learn with its Law Faculty. My wife and I extend special, deeply felt thanks to Dean Eyal Zamir, Associate Dean Maly Lichenstadt, and the staff at the Law Faculty for the warmth, support and generosity shown to us during our stay in Jerusalem. Thanks are also due to Dr. Guy Pessach of Hebrew University for providing helpful suggestions and comments on this draft, to the members of the Law Faculty of Hebrew University who participated in a discussion of this paper during my visit at the university, and to Dr. Barak Medina who was very helpful in providing me with English translations of various proposals to amend the copyright law in Israel, as well as working with me to prepare this essay for publication. Finally, and most importantly, I owe my wife Elizabeth Langer special thanks for her enthusiastic support of our journey to Israel and her careful critique of my writing. 
course, are legitimately made. In American intellectual property law, the fair use doctrine grants certain uses of copyrighted materials a privileged, royalty free position. Educational uses of protected works-duplication for classroom use, scholarship and research-are among those expressly protected.' While the scope of the protection is not entirely clear, ${ }^{2}$ it is jealously guarded by teachers and librarians. In addition to the teaching and research privileges granted by the fair use doctrine to educators, scholars may duplicate their own unpublished work or material that is in the public domain. Many school administrations have established systems to assist faculty in obtaining permission to use copyrighted materials when the fair use rules do not apply. Most of the copying, therefore, is probably legitimate. But even making a very conservative guess that only ten percent of the copies of protected items at universities are made both without explicit permission from copyright owners and outside the scope of the fair use rules, universities unlawfully create the equivalent of 5,000 books of 200 pages each for every ten million pages they duplicate per year. ${ }^{3}$ Over a ten year period, this duplication rate is the equivalent of a very respectable library of 50,000 volumes. And, of course, the amount of university copying pales before the totality of copying at all large institutions and businesses in the United States. It is fair to assume that each year major organizations in the United States copy enough material without permission and outside the scope of the fair use rules to create the world's largest library.

Such copying of written material is only the tip of the iceberg. In advanced countries, millions of people have in their homes and offices the equivalent of what was considered a major publishing enterprise a couple of decades ago. Computers, tape recorders, copy machines, scanners, CD and DVD players and burners, an array of digital data storage units in computers, cable and satellite television receivers and other devices, and instant international communications systems are at our fingertips. With the push of a button we can send or receive large documents, pictures, audio and video recordings, pictures and other graphic materials and any other item that can be digitally stored almost anywhere in the world. Napster, Aimster, Kazaa, Grokster and their imitators allow computer users to pool and search huge libraries of digital files, select ones they want and download them in seconds. ${ }^{4}$

17 U.S.C. $\$ 107$.

2 For more information on this issue see infra $\mathrm{n} .76$.

3 This sort of "seepage" rate of illicit copying-ten percent-is actually not very large. Many enforcement systems would be delighted with such a compliance rate. It is also clear that using a baseline figure of ten million represents only a tiny fraction of university copying in the United States. Duplicating machines at Georgetown University Law Center alone produce more than twenty million pages in a single year.

4 Several important decisions have been rendered on the legitimacy of Napster, Aimster, Grokster and other similar systems. In A \& M Records v. Napster, Inc., 239 F.3d 1004 (9th Cir. 2001) and); 
This is certainly not news in either Israel or the United States. As a technologically sophisticated country, Israel has been living with a similar situation for some years now. But those who drafted the Copyright Code in the United States during the 1950s and 1960 s could not have envisioned recent technological advances. And certainly those who wrote the core of Israel's copyright code, which was put into effect during the British mandate period, were addressing issues from a vastly different perspective. Trying to catch up to technological developments in recent decades has led to a series of important amendments to the United States' copyright code, none of which has been successful. And the reason, in my view, is simple, straightforward and, at least in America, controversial. The underlying structure of contemporary copyright law is broken-badly broken. It doesn't work in this digital age.

The core of the problem lies in the wide distribution of cheap copying technologies. Individuals and businesses can make perfect copies of digital materials at very low cost. Moral inhibitions on making copies are disappearing. Many people now view popular music, for example, as theirs for the taking-as a public good. ${ }^{5}$ Owners of copyrights have discovered that they can easily lose control over the distribution of their works. If they respond by imposing significant limitations on digital access, the community of readers and users of creative works-including those justifiably claiming access under fair use rules-may decline. Events suggest we are getting caught between a rock and a hard place. Many digital works are becoming either too easy to copy or too difficult to obtain. Some produce sub optimal revenue because of copying while others reach smaller than optimal audiences because of restrictions on distribution imposed by technological controls or copyright laws. ${ }^{6}$ Such results

In re Aimster Copyright Litigation, 334 F.3d 7643 (7th Cir. 2003) the courts concluded that such online systems violate the copyright code. In a similar case involving Grokster, Ltd. v. MetroGoldwyn-Mayer Studios, Inc., 380 F.3d 1154 (9th Cir. 2004), however, the opposite result was reached. The United States Supreme Court recently reversed a Ninth Circuit opinion that had allowed the company has agreed to distribute file sharing software "passively"- that is, by not providing any online assistance to those exchanging files. Grokster, Ltd. v. Metro-Goldwyn-Mayer Studios, supra. The Supreme Court concluded that purveyors of file sharing software violate the code if they know their products will review this result in substantial third party copying of protected works and promote its use for that purpose. Metro-Goldwyn-Mayer Studios, Inc. v. Grokster, Ltd., 125 S.Ct. 2764 (9 $9^{\text {th }}$ Cir. 2005). Further discussion of Grokster may be found infra at p. 101-102. (36-37)

5 See, for example, the web site of Peer 2 Peer United available at http://www.p2punited.org (Last visited September 2005).

6 Some of the vibrancy of the debate about the consequences of modern technology is visible on the web sites of the Berkman Center for Interent and Society at Harvard Law School available at http://cyber.law.harvard.edu/home/ (Last Visited September 2005) and the Stanford Law School Center for Internet and Society available at http://cyberlaw.stanford.edu/index.shtml (Last visited September 2005). 
frustrate the goal of American copyright law to balance incentives to create new works with their widespread distribution.

We need a new, more efficient, user-friendly copyright paradigm. That will require several steps. First, for most forms of mass media and digitized works, reliance on infringement litigation to control the misuse of protected materials must end. Second, legislatures should create flexible regulatory systems capable of responding to new forms of duplicating technology. And third, with the assistance of these new administrative regimes, owners of copyrighted material should receive royalties from the assessment of levies upon those who manufacture and distribute both reproductive devices and storage media. Efforts by copyright owners to obtain royalties directly from those who actually use digital technology to duplicate or distribute protected materials is impractical. Israel, now considering extensive revisions of its copyright code, could become a world leader in intellectual property reform by adopting such a system. ${ }^{7}$ What immediately follows is an excursion into the history of copyright law in the United States. The goal is to discover what the failures of American policy makers teach all technologically advanced countries about responding to the challenges of the digital age.

\section{Lessons From Three Slices of History}

Responding to new technological developments has long been a problem in the United States. From the invention of photography and the player piano in the late nineteenth century and sound recordings at the beginning of the twentieth century, through the development of radio, television, audio and video tape machines, computers and digital technology, legislative and judicial responses frequently lagged behind technological change and resulted in strange regulatory patterns. As difficult as it was for Congress to react to developments during the nineteenth and most of the twentieth centuries, the speed and scope of change in recent decades has outpaced the ability of legislatures and courts to respond. In addition, developments in this digital age are qualitatively different from anything that has occurred before, especially in the wide availability of inexpensive copying technology.

7 The revision proposal now being considered by the Justice Ministry rationalizes the various copyright laws that have been enacted since the original British law went into effect during the mandate, but does not include any dramatic changes in the existing philosophy of Israeli copyright law. See Memorandum of the Copyright Law, 5764-2003 (English translation available in author's files.) 
There is, therefore, dissonance between the ways America responded to technological change in the past and the sorts of reforms required today. Historically, Congress expanded the categories of materials and media eligible to obtain copyright protection as new means of expression emerged and enlarged the remedies available to copyright owners. By and large new copyrightable forms of expression were absorbed in some fashion into the existing copyright paradigm. ${ }^{8}$ The changes were often slow to arrive and not well conceived. But, for the most part, users, the major entertainment industries, media and other copyright related enterprises adapted and survived without major economic damage. That is no longer possible. This is made quite clear by comparing two of many technological developments of the twentieth century-the invention of sound recordings and the arrival of video tape recorders-with recent responses to the digital age. Below I explore the impact of these three technological developments on copyright law and use them to explain why our present plight is so problematic.

\section{A. Sound Recordings}

The extant structure of protection for sound recordings in the United States arose out of a bizarre series of events involving the player piano. This device was invented at the end of the nineteenth century. Users inserted into the piano a scroll of heavy paper with perforated holes marking the notes to be played. In the first commercially successful machines, foot pedals were used to create suction in a tube with holes in it, one for each note. As the holes in a scroll passed over the holes in the tube, the vacuum in the tube would be released causing the machinery to play a note. Later machines ran on electricity. ${ }^{9}$ These instruments were quite popular. Prior to their appearance, many middle and upper class households had regular pianos as well as family members who knew how to play them. Player pianos, which also could be played by hand the oldfashioned way, extended the repertoire of music available to a household and allowed group sing-alongs-a common form of evening entertainment before the advent of radio and television-even when the musician of the household was not present.

8 Much of the history about enlargement of the scope of copyright is laid out in the famous cases of Burrow-Giles Lithographic Co. v. Sarony, 111 U.S. 53 (1884) and Bleistein v. Donaldson Lithographic Co., 188 U.S. 239 (1903). Sarony involved the copyrightability of a beautiful photograph of Oscar Wilde and Bleistein the status of circus advertising posters.

9 A brief and lucid description of early American player pianos is available at http://www.pianola. com/pphist.htm (Last Visited September 2005). For a more complete history, go to http://www. amica.org/Instruments/Player_Pianos/Player_Piano_History.htm (Last visited September 2005). 
Not surprisingly, the various makers of these devices each created their own format for the paper scrolls. The scrolls of one manufacturer would not work in the pianos produced by other companies. Two problems emerged in this market. First, the piano makers insisted that for copyright purposes the scrolls were not copies of the underlying musical compositions. Rather, they insisted, the scrolls were devicesparts of a machine. Second, the mechanical connections between the pianos and the perforated piano scrolls increased the likelihood that a monopoly would develop in the player piano market. Standardization in format was desirable. Consumers, highly unlikely to purchase more than one piano, sought out the unit with the greatest variety of piano scrolls available for purchase. The manufacturer lucky enough to hit on the right format-Aeolian Company as it turned out - gained a significant advantage in the market. ${ }^{10}$

The copyright status of piano rolls came before the United States Supreme Court in 1908. In White-Smith Publishing Co. v. Apollo Co." the justices, intellectually limited by a nineteenth century vision of creative works as articles understandable by sight, concluded that a piano scroll was not a copy because it was not in "intelligible notation." If the user could not perceive the nature of the work by sight it was not an object of note for copyright purposes. The manufacturers and sellers of the scrolls, therefore, did not have to pay royalties to composers of the music.

Congress, then drafting what became the Copyright Act of 1909, responded to the decision with what must have seemed like a remarkably sensible set of provisions. Concluding that the "intelligible notation" standard was both unworkable and unfair to the owners of copyrights in musical compositions, Congress gave owners the right to control the first "mechanical reproduction" of their works. In addition, afraid that the Aeolian Company would become a monopolist and force copyright proprietors to sign contracts giving Aeolian exclusive rights to their works, Congress created a compulsory licensing system. Once a composer licensed the mechanical reproduction of a work to one company any other piano scroll maker could enter the marketprovided they paid a royalty of two cents per scroll. ${ }^{12}$ By these simple steps, Congress both protected the interests of those who held rights in music and created a competitive market in the piano rolls.

The legal changes also were compatible with the standard American vision of the purposes of copyright law. Traditionally, the United States Supreme Court has opined that copyright law's primary purpose is utilitarian-to create the level of

${ }^{10}$ This process, of course, is familiar to all who use Microsoft Windows.

1 White-Smith Music Publishing Co. v. Apollo Co., 209 U. S. 1 (1908).

$12 \S 1(e)$ of the Copyright Act of 1909. 
incentives necessary to maximize the distribution of works to the public. ${ }^{13}$ While copyright law in most of the rest of the world is designed to protect the natural rights of individuals to receive remuneration for and to protect the integrity of their creative endeavors, ${ }^{14}$ the United States claims it will limit the rights of copyright owners to control distribution and dissemination of copyrightable works so long as incentives are large enough to induce continued creativity. ${ }^{15}$ The structure of rules fashioned for player piano scrolls enhanced the distributional potential for musical compositions in two important ways - by increasing competition in the manufacturing of scrolls and by removing the ability of copyright owners to control the distribution of scrolls after the first license for placing a composition on a scroll was granted. ${ }^{16}$

13 A recent example of that view is Feist Publications, Inc. v. Rural Telephone Service Co., 499 U.S. 340 (1991). The Court declined to allow a "sweat of the brow" theory of originality govern a dispute about the copyrightability of telephone directories. A work, the Court said, must have some minimal level of creativity in order to gain protection. Works requiring significant amounts of labor to create often contain facts or data, just the sorts of material American courts insist should be widely (and often freely) distributed. Before computers made the creation of telephone books from customer data bases simple, it took a great deal of time and effort to compile them. Under those circumstances it was tempting to extend copyright protection to them. But today, preparation of alphabetized telephone directories requires neither a significant amount of labor nor much ingenuity. Under such circumstances it is not surprising that the Court left them in the public domain.

On the "sweat of the brow" issue, Israel presents an interesting case. To some extent the decision in the Dead Sea Scroll cases relied upon the labor required to reassemble a fragmented scroll. An English translation of the opinion is available at http://lawatch.haifa.ac.il/heb/month/dead sea. $\mathrm{htm}$ (Last Visited September 2005). The trial level opinion is also available in English in David $\mathrm{L}$. Cohen, "Copyrighting the Dead Sea Scrolls: Qimron v. Shanks" (2000) 52 Maine L. Rev. 379, 399.

${ }^{14}$ Civil law countries frequently claim that their codes are designed to protect the natural creative talents of those making new works. They therefore tend to provide larger realms of protection than America. Lending rights, moral rights and performance rights, for example, are likely to exist in countries outside the United States. The American work for hire rules, which grant to companies control over the creative work of their employees and other workers, also are less prevalent in the rest of the world. See the definition of "work for hire" in 17 U.S.C $\$ 101$ and the ownership provisions in 17 U.S.C. $\$ 201(b)$.

15 The claims about the purposes of American copyright law made in cases like Feist, supra n. 13, certainly are debatable on a number of levels. The remedial structure of the code, for example, is not really market based. Rather than relying on a contract-like system of rewards, copyright uses a tort-like scheme. The calculation of "actual" damages is not based on a market formula, statutory damages are available as an alternative form of relief and attorney's fees may be awarded to a prevailing party. 17 U.S.C $\$ \S 504-505$. On a more sophisticated level, some make the claim that certain types of strong copyright law, such as the enhancement of protection for technological controls over the distribution of works under the Digital Millennium Copyright Act, 17 U.S.C. $\S \S 1201$ et seq., actually reduce the distribution and use of copyrighted works. See, e.g., Guy Pessach, "Copyright Law as a Silencing Restriction on Non-infringing Materials-Unveiling the Scope of Copyright's Diversity Externalities" (2003) 76 S. Cal. L. Rev. 1067.

${ }^{16}$ Licensing control by owners is an important issue in developing a new copyright paradigm. Without reducing the ability of owners to oversee the distribution and dissemination of their works, it will 
Was the Congressional solution perfect? No. The sensibility of these narrowly drawn enactments unraveled within a generation. Record players, sound recordings and radios emerged from the laboratories and became extremely popular in the first decades of the twentieth century. The impact was far reaching. The player piano market virtually disappeared. ${ }^{17}$ And, of course, the copyright status of sound recordings had to be resolved. This time Congress did not step in. Instead the involved industries, and eventually the courts, agreed to treat sound recordings like piano scrolls-as mechanical reproductions of the underlying compositions-by applying the piano scroll provisions of the 1909 act to sound recordings. ${ }^{18}$ There was an anomaly in this outcome. Piano scrolls did not reproduce the talents of a performer. When the new fangled sound recordings were played, however, listeners heard (scratchy) versions of the performers' talents. Treating records like piano scrolls provided royalties to the owners of musical compositions when the records were publicly performed, but not to the performers who made the sounds.

This result is still largely embedded in American copyright law. ${ }^{19}$ Though there was a vigorous debate in the 1970 s about whether the exclusion of musicians from the performance royalty stream was rational and fair, ${ }^{20}$ only the arrival of digital audio

be impossible to develop a more efficient online distributional system. This idea is developed later in the paper, infra Section $\mathrm{II}(\mathrm{C})(2)$.

${ }_{17}$ Culturally the combined effect of player pianos, sound recordings and radio substantially reduced the propensity of Americans to learn how to play music. In most middle and upper class homes, playing and singing music was a common form of entertainment. After the radio became a common consumer good, sales of sheet music and pianos fell, and fewer people learned how to play an instrument.

18 This result was not affirmed in the courts until 1942. Skilkret v. Musicraft Records Inc., 131 F.2d 929 (2d Cir. 1942).

1917 U.S.C. \$115. Performers do get paid when recordings are sold. This is both because the performers generally will not agree to make a record unless they receive remuneration and because under the present code, the precisely identical sounds embedded on a sound recording are protected from unauthorized copying and sale. 17 U.S.C. $\$ 114$. (This protection, of course, has been deeply challenged by the proliferation of portable devices and internet systems for duplicating digital files.) But the performance of a sound recording on the radio or in another public setting produces royalties only for the composer, not the performer.

20 The original version of $\$ 114$ (d) in the Copyright Act of 1976 required the Copyright Office to study the issue of performance rights in sound recordings. Their report urged Congress to provide for such rights. Subcomm. On Courts, Civil Liberties and the Administration of Justice of the Comm. on the Judiciary, 95th cong., 2d Sess., Performance Rights in Sound Recordings (Comm. Print 1978). Hearings were held on a proposed bill in the late 1970s, but no legislation was adopted. Some of this history is recited and critiqued in David Nimmer, "Ignoring the Public, Part I: On the Absurd Complexity of the Digital Audio Transmission Right" (2000) 7 U.C.L.A. Ent. L. Rev. 189; Bonnie Teller, "Toward Better Protection of Performances in the United States: A Comparative Look at Performers' Rights in the United States, Under the Rome Convention and in France" (1990) 29 Colum. J. Transnat'l. L. 775. 
transmissions and digital tape recording machines in the 1990s led Congress to alter the performance rights structure originally established under the 1909 Copyright Act provisions on piano scrolls. ${ }^{21}$ Those arguing in favor of performance rights in the 1970s contended that the legal structure was irrational and unfair. Why, they asked, should the playing of a sound recording on the radio or in another public place be a royalty producing event for the owners of the composition but not for the performers who created the sounds? Those satisfied with the royalty structure noted that the ability of musicians to make money on tour was enhanced by the free advertising they received from radio stations playing their records..$^{22}$ Regardless of who has the best of this argument, there is no doubt that the legal structure of the United States was left dramatically out of sync with most of the rest of the world. ${ }^{23}$

But the lessons here go beyond the anomalous quality of United States law. For even if the best policy was to enhance performance rights for musicians and singers, ${ }^{24}$ many performers, particularly those who wrote their own compositions, thrived under the piano scroll system. The United States, and as Israelis can testify, the world, was not left without American sound recordings to play. But the story does confirm the difficulty of responding well to each new technology as it emerges. Moving a legislature to action is problematic. Once a system exists that can be made to "work"even though imperfectly - for the major involved industries, it is extremely difficult to alter. Entrenched economic interests take over and the process of rationalizing the copyright code comes to a halt.

Indeed, the history of copyright legislation in the United States is rife with Congressional use of industry representatives with countervailing interests to draft

217 U.S.C. $\$ 114(\mathrm{~d})$ was significantly amended by the Digital Performance Right in Sound Recordings Act of 1995. This legislation was further changed in 1998 and 2002 to deal with the explosion in digital broadcasts and the arrival of streaming audio transmissions over the internet.

22 And others responded that such a system penalized some musicians, including symphonies or "edgy" performers that rarely toured, those making music with complex equipment that can't easily be taken on tour, or small time musicians popular only in a local area. In addition, the lack of royalties meant that radio stations looked to recording companies for material to play, sometimes demanding payoffs before broadcasting material. To the extent that such a payoff system operates it has the potential, in essence, to transfer performance royalties from the performers to the radio companies.

${ }^{23}$ In Israel, for example, broadcasting a sound recording is a royalty producing event for both the composer and the performer. Article 2, Performers' and Broadcasters' Rights Law of 1984 (1996).

${ }_{24}$ Perhaps the anomaly was less noticeable when phonorecords first appeared. The recordings were scratchy and the quality of the performance was therefore difficult to evaluate. Today, however, recording quality is very good and the creative abilities of the performers are easily discemible. 
compromise statutory provisions that are then enacted into law. ${ }^{25}$ The statutes resulting from such a process tend to be focused on specific problems and devoid of well considered, thoughtful provisions. The history of sound recordings is a stellar example of this process. The original piano scroll provision was designed to deal with a specific problem. Later, Congress was free to ignore the invention of sound recordings because the "mechanical reproduction" language of the piano scroll provision was, with a mild linguistic stretch, applicable to sound recordings. Despite the presence of a new interest - that of the performers whose work was recorded-the important interests in the sound recording and radio industries successfully barred the consideration of performance rights legislation, during the deliberations leading up to the adoption of the Copyright Act of 1976 and the later review of performance rights by the Copyright Office. ${ }^{26}$

The process repeated itself when the arrival of digital audio transmissions threatened the interests of the sound recording industry. Each digital copy of a digitally transmitted song is the same quality as the original. Numbers, after all, do not deteriorate as one tape is used over and over again to make another. Pre-digital, analog tapes of radio transmissions, however, are of lower quality and deteriorate with use over time. In addition, an analog copy of an analog tape is never as good as the one copied. The fear that digital tape recorders would be used to make many perfect copies of digital tapes drove the relevant industrial players - the radio and recording industries-- to craft a compromise and see to its adoption by Congress. ${ }^{27}$

Three major steps were taken. First, manufacturers of digital tape recorders agreed to install a Serial Copy Management System in every device, allowing for only one copy of a digital tape to be made. Second, manufacturers agreed to pay statutory royalties on the manufacture or importation of both digital audio tape recorders and digital recording media. The royalties were to be pooled and paid to composers. Finally, direct suits against consumers for making copies on the digital recording machines were barred.

Almost before the ink was dry on the Audio Home Recording Act of 1992, the legislative compromise was humbled by the advent of much more pervasive digital

25 This pattern is well described in Jessica Litman, "Copyright, Compromise, and Legislative History" (1987) 72 Cornell L. Rev. 857. The Copyright Act of 1976 was a partial exception. Many of the basic provisions resulted from careful study. But here too a number of compromise provisions resulted from industrial bargaining, including, among others, language in the fair use rule $(\$ 107)$, exemptions for certain performances and displays $(\$ 110)$, secondary transmissions by cable television $(\$ 111)$ and performances on juke boxes $(\$ 116)$.

${ }^{26}$ For more on the Copyright Office review, see supra n. 20.

${ }^{27}$ The core of the compromise may be found in 17 U.S.C. $\$ 1001$ et seq. 
technologies. The act's drafters, not anticipating the degree to which personal computers soon would become all purpose recording devices, exempted them from its coverage when computer makers objected to proposed statutory language that included their products. ${ }^{28}$ Much like player pianos, digital tape recorders had only a brief moment of glory. Today virtually no money is paid into the royalty pool. The variety of digital recording devices and internet transfer protocols now available left digital tape recording a derelict - an artifact of history. The legislation on this specific technological advance was doomed to fail.

Further sound recording dilemmas were raised by performance rights societies. In the 1990s they correctly claimed that perfect copies of recordings could be made from digital broadcasts by digital recording devices and argued that digital transmissions were equivalent to the distribution of duplicate recordings-a practice barred by $\$ 114$ of the code. ${ }^{29}$ Congress responded to these concerns in 1995 by adopting the Digital Performance Right in Sound Recordings Act. The legislation established sharply limited performance rights in sound recordings for the first time in American history. The terms of the legislation ${ }^{30}$ are quite complex. The intent was to require payments into a royalty pool for transmissions that substitute for purchases. Examples include interactive transmission systems in which users may select compositions or radio transmissions of entire albums based on previously published schedules. While this scheme continues to produce royalties, non-transmission systems for distributing sound recordings have significantly reduced its importance. Congress seems destined never to be able to catch up. ${ }^{31}$

\section{B. Video Tape Recorders}

Treatment of video tape recorders in the United States has also traveled down a blind alley, though this time without the intervention of Congress. The United States Supreme Court was the instrument of failure in this famous, or for me, infamous story.

${ }^{28} 17$ U.S.C. $\$ 1001(3)$ limits coverage to devices with a primary purpose of making digital audio copies for personal use.

${ }^{29}$ Under $\$ 114$ the rights of performers in sound recordings originally were limited to the right to control the distribution and use of the actual sounds fixed in the copies. As noted in the text, greater performance rights were added only with the advent of digital tape recorders.

$30 \$ 106(6)$ was added creating a performance right in digital audio transmissions and that right was subjected to numerous limitations in $\$ 114(d)$.

${ }^{31}$ Indeed the performance rights legislation has already been amended twice since its adoption in 1995-once in 1998 and again in 2002 - to deal with the impact of radio webcasting. For more on these recent developments see Joseph Magri, "New Media-New Rules: The Digital Performance Right and Streming Music Over the Internet" (2003) 6 Vand. J. L. \& Prac. 55. 
Sony Corporation of America v. Universal City Studios, Inc. ${ }^{32}$ is well known to Israeli intellectual property mavens. Concerned that Sony's Betamax video tape recorder ${ }^{33}$ would allow consumers to make copies of televised shows and movies, motion picture companies sued manufacturers of the devices and a consumer who admitted to copying movies. They argued that the consumer infringed copyrights by his use of a video tape recorder and that the device manufacturers were also responsible as vicarious or contributory infringers.

Unfortunately, the structure of the litigation - at least in hindsight—was quite strange. The proofs at trial demonstrated that the primary use for video tape machines was to "time shift." That is, consumers used the timer on the machine to make a copy of a show while away from home so they could watch it later. That sort of copying, the consumer defendant claimed, was protected by the fair use rule. The manufacturers also claimed the benefit of fair use. How could they be responsible for infringement if the machine's user did not violate the copyright act? In addition, they argued that standard vicarious and contributory liability rules did not ensnare them. ${ }^{34}$ Responding to these issues, the Supreme Court constructed its opinion to answer two narrow questions. First, was "time shifting" protected by the fair use rule? And second, if it was, were manufacturers of video tape recorders responsible for unlawful utilization of the machines if the recorders were capable of "substantial noninfringing uses"? ${ }^{35}$ It makes no sense to rehearse the outcome of the case here in great detail. The literature on it is voluminous and the outcome is well known. Having narrowly structured the issues in the case, the Court concluded that time shifting was fair use and that video tape machines therefore had substantial noninfringing uses.

32464 U.S. 417 (1984).

${ }^{33}$ The recording format on Sony's Betamax differed from that of the rest of the industry. Though widely recognized as the better technology, consumers usually purchased cheaper machines using the VCR standard. When businesses first opened renting video tapes to consumers for home use, tapes were available in both formats. As consumers moved to the VCR format, however, movie makers stopped making Betamax tapes. That sounded the death knell for the technology. My Betamax machine became as useless as a player piano!

${ }^{34}$ In American law, vicarious liability is imposed on parties who control the venue or system used to copy, perform or otherwise infringe a work and receive financial benefit from the activity. The classic case is Shapiro, Bernstein and Co. v. H.L. Green Co., 316 F.2d 304 (2d Cir. 1963), which involved a chain of department stores selling counterfeit recordings. Contributory infringement arises when a party knowingly contributes to or induces unlawful activity. A leading case in this area is Fonovisa, Inc. v. Cherry Auction, Inc., 76 F.3d 259 (9th Cir. 1996), in which the operator of a flea market was found responsible for the actions of parties renting space in the market and selling counterfeit recordings. At times it is difficult to tell the difference between the two theories.

35 The Court viewed this formulation of the question as the best balance between protecting the interests of copyright owners and creating appropriate incentives for industrial inventors to bring new products to the market. 
Given the way the Supreme Court structured the case, the result made sense. No one was interested in policing the private use of video tape machines in peoples' homes. And if time shifting was the primary use of the machines, the harm to owners of copyrights in TV shows and movies was minimal. Indeed, time-shifting may have produced more rather than fewer viewers of some shows. But, as with piano scrolls and digital tape recorders, the Court was able neither to predict the future nor to control the way their opinion would be read and implemented. Within a short time, it became clear that video tape recorders both enhanced and endangered the film market. On the one hand, video tape rental businesses blossomed and large quantities of recorded movies were purchased from the studios. On the other hand, some consumers duplicated tapes and created movie libraries. In the long run, the Sony opinion, read culturally as granting a "privilege" to individuals to use recording machines as they wished in the confines of their homes, became the comer stone for contemporary arguments that consumers should be free to use personally owned duplication devices as they please.

It is difficult to be too critical of the Sony Court. The result worked well for a time, just as the piano scroll regulatory structure worked passably well in the sound recording industry before the arrival of digital copying technologies. We can't expect the Justices, any more than we can expect legislators after the invention of piano scrolls, record players and digital tape recorders, to craft prescient results that fully account for future developments. But, in fact, they did miss a glorious opportunity to begin a copyright reconstruction project that would have laid the foundation for resolving many of today's problems. What could they have done? Before answering that question, we need to take a slight detour to review the nature of the problems faced by the United States in the wake of the failed efforts to regulate digital technology's impact on copyright law.

\section{Digital Technology}

As noted, both the institutions creating copyright law in the United States and the relevant markets responded to the invention of sound recordings and video tape recordings with plausibly satisfactory results. Performers obtaining plays of their records on radio stations and in other media benefited from publicity that enhanced the value of their performing careers. Recording companies also had to pay for the services of performers in order to put out their recordings in the first place. It was not a market, therefore, in which performers totally lacked economic power. The underlying purposes of copyright law - the American preference to maximize the distribution of 
works by creating incentives for their creation and marketing or the civil law desire to reward creativity because of its inherent natural value-were arguably served even though performance rights in sound recordings were limited.

Similarly, after the Sony decision, the movie makers' fears that their products would be "stolen" as owners of tape recorders amassed libraries of movies were mollified by the emergence of the video tape rental business. Rental chains purchased large numbers of tapes to rent after the first and second runs of movies were completed. And movies that studios never released for showing in theaters for one reason or another were often sold to the rental bazaar. In short, video tape machines unexpectedly created a new and burgeoning market for the very works thought to be put at risk by the recorder's invention. Though some consumers used the machines to amass libraries of movies, the larger entertainment world adapted to the machines with a workable compromise between the interests of equipment manufacturers, movie houses and consumers.

But for several reasons no such market accommodations appear likely to arise in the digital world. Though the pace of technological innovation in today's world is breathtaking, it is not just the swift pace of change that marks this as a unique era. ${ }^{36}$ The nature of the change is also new in several distinct ways. First, the widespread availability of digital technology in private homes as well as in large businesses and institutions means that the systems used to distribute many sorts of copyrighted works are now out of the control of copyright owners. Once a work is released, it can propagate like a virus. Computers, recorders, MP3 players, the internet and an array of software platforms, to say nothing of copying and distribution techniques yet to appear, create too vast a copying arena to expect satisfactory market responses and accommodations between media companies, equipment manufacturers, creative individuals and the consuming public.

Second, the ubiquitous nature of digital technology has dramatically altered the relative costs to consumers of buying as opposed to copying a work. Creating a personal library of movie tapes, for example, was not an economically attractive practice for most people. In addition to the costs of the video taping equipment and the blank tapes, the process took a lot of time and produced tapes of significantly lesser quality than the originals. For most people it made more sense to rent or even purchase decent quality tapes. With many digital works, however, copying costs and other expenses are de minimis. While the initial cost of a computer can be significant, most consumers

36 Indeed, those living at the beginning of the twentieth century may have felt the same way we do about the pace of technological change. Within a few decades around the turn of the century, electricity, the telegraph, radios, record players, high-rise buildings and the automobile became common. 
spread that cost over a host of uses-home accounting, business undertakings, word processing, tax preparation, internet surfing and a myriad of other activities. As the cost of computers fell in recent years, the actual investment attributable to copying digital files shrunk to a fairly low level. In addition, duplication media, such as blank CDs and DVDs, are inexpensive. And the time requirement is minimal. Many files take only seconds to copy. Larger files can be downloaded while the computer is used for other purposes. Though individual consumers may have moral qualms about copying protected works, downloading a digital file is very attractive economically. That's a formula for trouble, especially among students and other young people who are computer savvy and not yet fully embedded in the labor market. ${ }^{37}$

Third, copyright protection systems designed by copyright owners afraid of losing control over their markets can be all encompassing, limiting access not only of those who may have no right to use the work without payment, but also of those who may justifiably claim a right to access a work under fair use rules. The creation of systems limiting digital copying is in the hands of copyright owners. There are no incentives for them to develop special protocols for users claiming a privilege to pay less than full price for access. Some copyright owners are developing systems to limit the number of copies of a work users may make and control the pathways by which a work can be distributed. Entertainment, software and other companies also have responded to the arrival of digital duplication devices by seeking and obtaining Congressional action to harshly punish those who interfere with the operation of digital copyright protection systems. ${ }^{38}$ Sometimes the systems are "hacked." But the systems limiting access are becoming much more sophisticated and quite often work. ${ }^{39}$

${ }^{37}$ Recently some record companies and storage device manufacturers have established websites for the distribution of music repertoires, allowing each tune to be downloaded at a relatively low price such as 99 cents. This may reduce the degree of peer-to-peer file sharing, at least among those with some moral sensibilities about copying protected works. But it is hard to believe that such systems will have a serious impact on the overall use of peer-to-peer systems.

${ }^{38}$ Prior to the digital age, software companies sometimes attempted to place systems in their software that barred making copies. At an early point in the history of Word, Microsoft imposed a primitive copy limitation on the software. It was easy to subvert and caused antipathy in the market. It was soon withdrawn. Most consumer software published since has not contained any copy limitations. But copy limitations systems are now having a comeback, particularly with the distribution of online updates that will not install without use of the original CD containing the program.

39 This is especially true with web based distribution systems requiring payment for access and barring downloading. But once a work has been sold and downloaded it usually becomes just another easily distributed digital file. That may well change as file marking and control systems become more sophisticated and their use more widespread. For discussion of the capabilities of digital management systems, see P. Bernt Hugenholtz, Lucie Guibault and Sjoerd van Geffen, The Future of Levies in a Digital Environment: Final Report (Amsterdam, Institute for Information 
Finally, the terms of the present debate-at least in the United States-have become polarized and harsh..$^{40}$ The issues are presented as two starkly different alternatives. Major copyright owners claim, with some justification, that a digital work released without any system limiting its duplication and distribution becomes a public good. They insist upon the right to completely control the distribution of their works and sharply criticize efforts to undermine technical controls over distribution and duplication. Since millions of consumers have the capacity to copy protected works at very low cost, they argue, incentives to produce a creative work are substantially lowered and the natural worth of expressive activity goes under-rewarded. As a result owners contend that copyright protection systems are mandatory if entertainment markets are to be protected. This view leads to a world in which everyone-regardless of their status under fair use rules or any other privileged copyright position-must pay for a digital work or forego using it.

Others, also with some justification, worry that continued access to the cultural fabric of the nation is endangered by digital copyright protection schemes. They complain that allowing major copyright owners to completely control the distribution of their works undermines the ability to freely browse in the world of culture, ${ }^{41}$ diminishes or limits the utility of the fair use rules ${ }^{42}$ and restricts cultural inquiry by significantly narrowing the range of materials freely available to those wishing to

Law, 2003); Mark Stefik, "Shifting the Possible: How Digital Property Rights Challenge Us To Rethink Digital Publishing" (1997) 12 Berkeley Tech. L. J. 138. Major companies, including Microsoft, Time Warner and Thomson, have large stakes in Content-Guard, a company working on setting an industry standard for software designed to prevent unauthorized copying of music and movie files off the internet. "Thomson Buys Into Anti-Piracy Company" International Herald Tribune, 23 Nov. 2004, p. 16.

${ }^{40}$ The polarized nature of the debate is patent in the positions taken by the parties in the Aimster litigation. Indeed, the extreme positions of the litigants gave the courts lots of room to claim it was simply searching for a happy medium. In the end, Judge Posner refused both the music owners' claims that any copying assistance provided by online services was unlawful and Aimster's claim that online services were free of any responsibility for the uses made of their systems. Finding that Aimster could exercise some control over the uses made of its system, the court concluded that Aimster had the burden of proving that its service had substantial non-infringing uses and that imposing constraints on the system's use were costly or impractical. In re Aimster Copyright Litigation, 334 F.3d 643 (7th Cir. 2003).

4I This issue is probably best discussed in Julie E. Cohen, "A Right to Read Anonymously: A Closer Look at 'Copyright Management' in Cyberspace" (1996) 28 Conn. L. Rev. 981. Browsing, she argues, is an essential part of deciding which creative works to study or read in depth. Using a library often entails walking by the shelves and briefly perusing a book in order to decide whether to check it out. Cohen worries that copyright controls will, among other things, remove our ability to browse in the online world of culture.

${ }^{42}$ Julie Cohen has also written at length about this problem. See Julie E. Cohen, "Copyright and the Perfect Curve" (2000) 53 Vand. L. Rev. 1799; Julie E. Cohen, "Lochner in Cyberspace. The New Economic Orthodoxy of 'Rights Management" (1998) 97 Mich. L. Rev. 462. 
enrich society with new creative works. ${ }^{43}$ Protecting the value of copyrights held by the major entertainment companies is not the problem they argue. Rather the continued ability of all citizens to gain access to the materials they need to do research, create new works and enhance the vitality of their lives is at risk.

The most recent salvos in this debate surfaced in American Library Association v. Federal Communications Commission-litigation over the legality of regulations issued by the FCC requiring receivers of over-the-air digital television broadcasts (digital television receivers or DTVs) "to be manufactured with the capability to prevent unauthorized redistribution of digital content." The rules mandated that each receiver be able to detect a "broadcast flag" and use it to trigger electronic limitations on copying. The rules were challenged by the American Library Association and other user groups. The Motion Picture Association of America and other copyright owners intervened on the side of the Commission to support the regulations. The court described the arguments of the parties during the rule-making proceeding as follows: ${ }^{44}$

Unsurprisingly, there was an enormous response to the [...] [regulations when they were proposed by the Commision]. The Commission received comments from, among others, owners, producers, and distributors of broadcast television content; consumer electronics manufacturers; consumer interest groups; library associations; and individual consumers. Content owners and television broadcasters argued that, if DTV broadcast content was not protected from the threat of widespread unauthorized redistribution via networks such as the Internet, high value content would migrate from broadcast television to pay television services, which offer a more secure distribution channel. See Digital Broadcast Content Protection, 18 F.C.C.R. 23,550, 23,553 (2003) ("Flag Order"); Joint Reply Comments of the Motion Picture Association of America, Inc., et al., 2/20/03. But there was also overwhelming opposition to the proposed broadcast flag rules. As Commissioner Adelstein noted: "Thousands of people contacted us and urged us not to [adopt the broadcast flag regime]. Many consumers are concerned about the effect on their use and enjoyment of television, as well as their personal privacy." See Flag Order, 18 F.C.C.R. at $23,620[\ldots]$. Opponents of regulation argued that the threat from content redistribution was overstated in light of technological limitations to widespread Internet retransmission. See id. at 23,553. In addition, critics of the proposed rules expressed concerns about

${ }^{43}$ See, e.g., Jessica Litman, The Public Domain (1990) 39 Emory L. J. 965.

44406 F.3d 689 (D.C. Cir. 2005). 
implementation costs and suggested that the broadcast flag both was an inadequate tool to protect content and would stifle innovation.

Though the court found that the Federal Communications Commission lacked authority to issue the broadcast flag rules, ${ }^{45}$ the dispute typifies the structure of contemporary debate between copyright owners and content users. Owners claim overwhelming financial harm. Equipment manufacturers simply want to build and sell devices. And users want fast, untrammeled access to digital materials. So far, the major copyright owners have won the debate in both the United States and the European Union. The Digital Millennium Copyright Act of $1998^{46}$ placed significant limitations on the ability of private parties to interfere with the copyright protection systems now being put into place in many segments of the copyright market. Though the act states that it has no affect on "rights, remedies, limitations, or defenses to copyright infringement, including fair use," to protect such interests when they create copyright management systems. The Motion Picture Association of America will certainly seek Congressional action to resurrect the broadcast flag rules. If past is prologue they may get their wish. The European Union has ended up in a similar situation. While Article 5(2)(b) of the Union's 2001 Copyright Directive allows member states to protect the right of private parties to make copies of works for personal use, "fair" compensation must be provided for such uses. In addition, the Directive contains strong language requiring the protection of "rights management information" in copyrighted works. ${ }^{48}$

It is not clear who will win this battle in the long run. While most would argue that the large media companies are the odds-on favorites, such an outcome is not preordained. At least in the United States, the lobbying power of libraries, universities, other major institutional consumers of copyrighted materials and a growing number of user and consumer organizations may make for any interesting contest. The outcome of the

45 The court concluded that the FCC has authority to deal with transmissions but lacks the power to issue regulations controlling what receiver owners do after they receive a broadcast.

${ }^{46} 17$ U.S.C. $\$ 1201$. Like the provisions dealing with digital audio tape recorders, this section is enormously complex. It contains narrowly drawn exceptions for libraries, reverse engineering and encryption research. But, as with fair use, nothing in the act requires the creators of copyright management systems to build in ways to use the exemptions.

4717 U.S.C. $\$ 1201(\mathrm{c})(1)$.

48 Articles 5(b)(2), 7(1)(a), Directive 2001/29/EC of the European Parliament and of the Council of 22 May 2001 on the Harmonisation of Certain Aspects of Copyright and Related Rights in the Information Society, Official Journal L 167, 22/06/2001 P. 0010-0019. The WIPO Copyright Treaty also requires nations to protect copyright protection systems. The treaty, for example, requires that "adequate legal protection" be provided against the circumvention of technical controls. 
litigation over the legality of the FCC's broadcast flag regulations certainly suggests that the ongoing arguments will be energetic. But this is an unnecessary debate. There is a new copyright structure, pieces of which have already been implemented in many countries, including Israel, that can rescue America and the rest of the world from the stark, polarized contours of the present digital dialog. That brings me back to Sony.

\section{The Solution}

\section{A. The Sony Case}

As noted above, ${ }^{49}$ the Supreme Court opined that it was confronted with two questions in the Sony case. First, was "time shifting" protected by the fair use rule? And second, if it was, were manufacturers of video tape recorders responsible for unlawful utilization of the machines if the recorders were capable of "substantial noninfringing uses"? The issues should not have been constructed this way. Machines and devices that allow users to undertake significant amounts of unsupervised duplication are an inherent risk to the value of copyrighted works. Even though the economic impact of any particular person's activity may be small, the cumulative impact may be significant. ${ }^{50}$ At the same time, enforcement efforts against individual machine owners are costly, highly controversial ${ }^{51}$ and frequently unsuccessful. Posing the issue in Sony by asking if devices have substantial noninfringing uses, therefore, was backwards. The Court should have asked if manufacturers knew the devices they made could be used for significant amounts of unsupervised, potentially unlawful duplication. Charting this path was difficult, however, for two reasons. First, application of standard contributory infringement rules was problematical. ${ }^{52}$ In addition, the formulation I suggest seems

49 Supra n. 13.

${ }^{\text {so }}$ Recall the comments at the beginning of this essay on the scope of copying at universities and other major institutions.

51 A good example is the recent suits brought by the record industry against hundreds of individuals, many of them youngsters or college students, using peer-to-peer programs to swap and download digital files. Though the defendants may be infringers, the cases have produced quite a lot of negative publicity. Student defendants, claiming poverty, angrily protested that they were merely attempting to gain access to music that is vastly overpriced at $\$ 15$ or more per compact disc.

52 Standard vicarious liability nules were probably inapplicable. They require the defendant to have control over the forum in which infringement occurs and to obtain financial reward from the infringing activity. See supra $\mathrm{n}$. 34 . While the makers of video tape recorders certainly derived income from sales of the devices, they did not have control over the ways consumers used them at home or at the office. 
to require finding that consumer use of duplication technology is infringing - a result few wished to reach. While neither obstacle, in my view, was a serious problem, it was not surprising that the Court chose another route.

The Court actually followed patent rather than copyright precedent in Sony. Justice O'Conner reasoned that the balance between the intellectual property owner's need for effective protection and the rights of others to engage in manufacturing and commerce was analogous in patent and copyright. She therefore applied the well known patent formulation for contributory infringement. But her logic was wrong. A valid patent provides a strong form of monopoly protection to its owner. Copyright proprietors rarely hold a true monopoly. ${ }^{53}$ Rather they merely gain the right to exclude others from using their particular form of expression. One expressive endeavor virtually always competes for customers in the market with other works in the same or related entertainment arenas-novels, plays and poetry with other literature, one painting with others in galleries, one piece of music with another, and so on. The need to protect manufacturing enterprises not holding patents from the potentially enormous impact of a monopoly enhances the need for limiting contributory infringement liability. The opposite is so in the case of copyright. The best analogy is not from patent law, but tort law. One who permits another to use an instrumentality knowing that it is likely to be used harmfully is responsible for the ensuing loss. ${ }^{54}$

The Court might also have feared holding video tape recorder manufacturers responsible for the uses made of the machines because of concerns about treating consumers fairly. The enforcement of copyright law against millions of consumers making copies of video tapes was an extraordinarily unattractive option. The potentially intrusive impact on consumers was unacceptable and the practicalities of policing the general public were particularly daunting. So, assuming that some sort of fair use protection would be extended to tape machine owners, was Sony still a contributory infringer? While at first glance the question seems to provide its own negative answer, that conclusion is not required. There are a number of settings in which criminal or civil liability may be imposed upon a party even though the primary actor in the drama emerges unscathed. The Model Penal Code, for example, provides that an accomplice may be prosecuted even if the primary actor is acquitted or never

\footnotetext{
53 And when they do obtain monopoly like status, it is because a copyright, or series of copyrights, operates in the market like a patent. Operating system software may be the best example. Because standardization is so important to the successful world-wide use of computers, a copyright on basic operational software will tend to operate like a patent. Windows, of course, is the prime contemporary example, though we should not forget piano scrolls.

$54 \$ 877(\mathrm{c})$, Restatement (2d) of Torts (1979).
} 
prosecuted. ${ }^{55}$ Similarly, a person may be a contributing tortfeasor even if the primary actor is never pursued or is somehow immune from liability. ${ }^{56}$

So too in copyright law. The fact that a primary actor has a defense to an infringement action should not bar imposing responsibility on a contributory infringer. Treating fair use as a defense that relieves a primary party from responsibility for activity that would otherwise be infringing says nothing about whether others, lacking access to fair use, should be liable. Sony was a perfect case in which to apply this principle. The most important reasons for allowing consumers to claim fair use when they copy a program from television relate to the special problems associated with policing their actions. The fear of "video police" raiding private homes, the difficulty of enforcing copyright law against millions of individuals, the weight of negative public opinion, and the relatively minor economic impact of each individual's actions make it appropriate to relieve consumers of direct responsibility. ${ }^{57}$

But none of these factors justifies excusing equipment manufacturers from liability. Indeed, their actions are the single most important factor in the creation of a widespread practice and culture of copying protected works-no machines, no problem. Given the basic purposes of either American or civil law copyright codescreating appropriate incentives for the production of original works or recognizing and rewarding the inherent value of creative endeavors-it is much more important to address the spread of duplicating technology than to attempt to police the actions of individuals in the privacy of their homes or offices. So the Supreme Court could, and should, have concluded that Sony was liable for the totality of infringing activity produced by its machines. ${ }^{58}$

What sort of system would have emerged after such a judgment? It is impossible to know for sure. But the importance of the markets for recording equipment, television

ss $\$ 206(7)$, Model Penal Code, Uniform Laws Annotated.

56 The basic contributory tortfeasor rules are described $\$ 877$, Restatement (2d) of Torts (1979).

57 This does not mean that the individual actions of people using duplication technology should have no impact on copyright policy. While the impact of individuals is small, the total impact of all users can be enormous. While policing systems directed at consumers might be unworkable and intrusive, that does not mean that other ways of extracting costs from consumers are also inappropriate. Imposing levies on equipment, for example, avoids the enforcement problems that drove the Sony Court. Further discussion of this issue appears later in this section of the paper.

${ }^{58}$ There is a technical statutory construction argument against this position. Section 107 of the Copyright Code provides that "the fair use of a copyrighted work [...] is not an infringement of copyright". It can be argued that this not only relieves a consumer of responsibility for her private use of copyright technology but also all others related to the activity. In short, declaring actions protected by fair use as "not an infringement" could be read quite broadly. But that construction is not required. The language could easily be deemed applicable only to the party successfully claiming that his or her actions were fair. 
and movies strongly suggests that the major players in the industries would have gotten together and developed a plan in which the manufacturers of recorders would have paid funds into a royalty pool to be distributed to the owners of works likely to be copied by the machines. All sides benefit from that result. The manufacturers are free to produce their machines and the movie and television industries obtain money for the duplication of their copyrighted films and shows when the machines are sold. Such a decisional model might have avoided some of the controversy that has followed. If manufactures of both equipment capable of duplicating copyrighted works and media capable of holding copies of such works knew they would have to pay fees into a royalty pool and purchasers of the equipment and media knew they would be left free to duplicate to their heart's content, the entertainment world would probably have accommodated itself to the new structure in fairly short order. Existing performance rights societies would have found the new terrain familiar and new groups claiming the right to royalty pools would quickly have arisen.

This prediction is lent some credence by the experience in Germany. Litigation quite similar to Sony bounced around in German courts during the 1950s and 1960s, with the Supreme Court finally holding in 1964 that the manufacturers of taping equipment might be contributory infringers. The dispute was settled by an agreement calling for payments to music societies by the tape recorder manufacturers. The legislature then stepped in and established a compulsory royalty system much like the one I advocate here. ${ }^{59}$ Similar systems were put in place by many other countries in the European Union in the following decades, as well as in other countries around the world. ${ }^{60}$ If only the Sony Court had followed suit.

Instead the result in Sony set the tone for much of what followed in the United States. Lacking any obvious legal constraints on the actions of either consumers or manufacturers of duplication devices, both were left free to pursue their own contradictory self interests. As the recent Supreme Court decision in Metro-Goldwyn Mayer Studios v. Grokster ${ }^{61}$ vividly demonstrated, the arrival of digital technology exacerbated the problem and caught America legally unprepared. While the Court tried to sidestep Sony to resolve the Grokster, it left intact the central dilemmas created

59 The story is told in Katerina Gaita and Andrew F. Christie, "Principle or Compromise? Understanding the Original Thinking Behind Statutory Licence and Levy Schemes for Private Copying" (2004) 4 Intellectual Prop. Q. 422 and in Hugenholtz, Guibault and van Geffen, supra n. 39, at 10-12. The tape recorder legislation has since been expanded to cover recording media and reprography. Ibid., at 436-37.

${ }^{60}$ As of 2003 twelve members of the European Union had such legislation and thirty other nations had some sort of levy system in place for various forms of private copying. Hugenholtz, Guibault and van Geffen, supra n. 39, at 13.

${ }^{61}$ Metro-Goldwyn Mayer Studios v. Grokster, supra n. 4. 
by Sony-enforcement and policing problems, along with the potentially inconsistent claims of legal right by both copyright owners and product users.

The legitimacy of Grokster's peer-to-peer file sharing software, widely used on the internet to exchange music and other protected materials, was challenged by MGM and other copyright owners. They claimed that under Sony Grokster was a contributory infringer-one with knowledge of direct infringement who materially contributed to the unlawful activity. In an interesting twist, perhaps dictated by disagreement among the Justices about the impact of Sony, the Court declined to use Sony logic. ${ }^{62}$ Instead the Court concluded that Grokster was a primary infringer-one who induces infringement by taking active steps to encourage others to undertake unlawful activity. Under such circumstances, there was no need to ask if the peer-topeer software at issue in the case had substantial non-infringing uses. Relying on what Justice Souter called "unmistakable" evidence of unlawful intent, the Court strongly hinted that the plaintiffs were entitled to summary judgment.

The Grokster result leaves the old problems with Sony intact and creates new problems all its own. In settings which lack the clear intention to induce copyright infringement found by the Court in Grokster, litigation about the legitimacy of technological devices will still use Sony contributory liability theories. Users still will claim a right to make copies of protected works for their personal use and inventors still will produce new devices easing access to digital works. Indeed, the result will create strong incentives for technology designers to keep quiet about the purposes of their inventions in order to evade use of Grokster's inducement theory. Over time it will become more and more difficult to distinguish between inducement and contributory liability factual settings. In addition, Grokster leaves intact all the previously discussed problems of copyright law in the digital age. To the extent that the decision actually results in declining use of peer-to-peer and other new technological systems to transfer files, fair use and other user rights will be reduced or eliminated. And to the extent to which the result fails to stem the still rising tide of digital copying, copyright owners may be denied their right to appropriate levels of compensation for use of their works. In sum, device manufacturers developed new machines and consumers copied. The arrival of digital technology exacerbated the problem and caught America legally unprepared. Fortunately, models for solving the present copyright crisis are already

62 Justice Souter wrote the main Grokster opinion for a unanimous Court. But Justice Ginsburg, writing for herself and Justices Rehnquist and Kennedy, concluded that MGM might also prevail on a Sony contributory liability theory. In addition, Justice Breyer, writing for himself and Justices Stevens and O'Connor, argued that the defendant's prevailed under Sony. It seems likely there was no clear majority on whether Grokster was a contributory infringer under Sony. 
well known. In the United States, the digital audio tape recording legislation provides a good starting point. Analogous legislation has been enacted in Israel, Germany and many other parts of the world. ${ }^{63}$ What is missing in all of the legislation is a general structure covering all copyrightable works and a flexible regulatory system capable of quickly responding to new technological developments.

\section{B. The Future}

Though complex, the Audio Home Recording Act of 1992 established a much more appropriate legal framework than the Supreme Court did in Sony. By providing for the payment of fees by manufacturers of digital equipment and media into a royalty pool, barring litigation against consumers and requiring the distribution of moneys from the pools to owners of rights in musical compositions, Congress actually seemed capable of understanding the appropriate way to respond to digital copying technology. Similar approaches to limited areas of the digital realm have been adopted in other countries, including Germany and Israel. German law provides for pooling royalties from the sale of video and audio recording appliances and recording media, and photocopying machines. ${ }^{64}$ The Israeli copyright code mandates the creation of royalty pools for the home use of cassette tape players. ${ }^{65}$ The provisions place an effective levy of just over $5.25 \%$ on sales of blank cassette tapes and mandate the payment of these funds into a royalty pool for distribution to copyright owners. In addition, a proposal is now pending in Israel to create a levy system for all devices "upon which commercial recordings are generally copied for private purposes." In an effort to add flexibility for future technological developments, the Minister of Justice, after consultation with representatives from a variety of government agencies, is given the authority to decide which devices come within the parameters of the legislation. ${ }^{67}$

${ }^{63}$ Gaita and Christie, supra n. 59, report that compulsory levy systems of some sort exist in Austria, Finland, France, the Netherlands, Spain, Switzerland, Denmark, Italy, Belgium, Greece, Portugal, Sweden, Japan, and Canada, in addition to Germany and the United States (the digital audio tape legislation adopted in 1992 and now largely out of date). Ibid., at 423, n: 2.

${ }^{64} \S \S 54,54 a$, Act Dealing with Copyright and Related Rights. An English translation of the act is available in Friedrich-Karl Beier, Gerhard Schricker and Wolfgang Fikentscher, eds. German Industrial Property (Weinheim and New York, VCH, 1996) and Supplements.

65 This change was made in 1996, when the Performers' and Broadcasters' Rights Law of 1984 was amended and $\S \S 3(C)-(D)$ were added to the Copyright Ordinance. See also Paul Edward Geller, ed. 2 International Copyright Law and Practice (New York, Matthew Bender, 2003) \&8[2].

${ }^{\infty} 5 \%$ of the retail price, less the value added tax, charged to consumers is placed in the royalty pool. So for each NIS, the actual levy rate is $5 / 95$, or $5.263 \%$. Article D of the Copyright Ordinance.

${ }^{67}$ The proposal would add a new chapter on Recording Devices Levy to the Copyright Ordinance. Proposed Article 17D would require the Minister of Justice to "appoint an advisory committee 
Unfortunately, these enactments are just band-aids. They address a small portion of the digital copyright problem, leaving the future of copyright insecure. The goals served by such piecemeal legislation are good. They provide reasonable remuneration to the owners of copyrighted materials for the use of their works while allowing individuals to pursue their intellectual endeavors free of any obligations to seek permission to copy protected items. But for the future, both these goals and the scope of copyright reform need to be substantially broadened.

The actual problem extends much beyond the use of copying technology in the privacy of one's home. The same technology that makes it easy for people to copy music, download newspaper articles, store pictures on hard drives, save audio visual works or send digital files to others also is available in every imaginable commercial setting. Many of the problems of enforcement that have led us to treat home copying with sympathy also are present in the commercial world. Though we may be less concerned with "digital police" overseeing activities in business establishments than we are with their potential intrusion into private homes, there is no reason to expect such policing to be successful. The costs are high and most who duplicate protected material will not be discovered. If we agree that the scale of copying of protected works now occurring in both private and commercial arenas is unacceptably high and that the problems of enforcement are similar in both types of places, reform must look to the entire spectrum of copyright policy.

In a similar vein, the costs of obeying contemporary copyright law are no more acceptable for many commercial establishments than they are for individuals. Many consumers find it cheaper and quicker to download a music file than to obtain permission or pay the sometimes steep price for a CD. For commercial entrepreneurs and authors wishing to use an array of copyrighted materials in their work, the obstacles to obtaining permission also may be enormous. A simple example will suffice. A legal academic in the United States writing a new text book routinely uses an array of excerpts from various books and articles. Unless an excerpt is quite small, permission is required to use it. Getting that permission for dozens of items requires searching for the present owners of the copyrights, drafting and sending letters, waiting for responses and, if a fee is requested, deciding whether to pay the requested amount, bargain for a lower payment or substitute other material. From personal experience, I

[...] whose members shall be a representative of the Ministry of Finance, a representative of the Ministry of Justice and a representative of the Ministry of Education, Culture and Sport." After consultation with the committee, the Minister of Justice, according to proposed Article 17(e) would determine "the types of taxable devices to which this Chapter shall apply" and "the percentage of the consumer price of taxable devices to be levied." The flexibility created by this language would be a welcome addition to the code. 
can testify that this takes a great deal of time, time that could productively be used in other endeavors. The entire process reduces the willingness of teachers, researchers and authors to use copyrighted works in their writings-even if readers will benefit from exposure to them, increases the likelihood that materials will be copied and distributed without obtaining permission and undermines the public's willingness to obey the law. Everyone is harmed in such a setting-new authors who are forced to alter their writing strategies in order to avoid running the copyright gauntlet, prior authors who are deprived of royalties they might otherwise receive and readers who find fewer or less fulsome commentaries on prior works in the marketplace. ${ }^{68}$ Much of this cumbersome labor can be avoided. At least in cases where the duplication and dissemination of works containing protected materials involves use of digital methods, we should strive to create a system that removes costly barriers to the use of copyrighted material. In the case of textbooks, most of the sources typically used by authors are easily available online. Payments of levies for duplicating equipment and media could easily substitute for the present burdensome, use-by-use permission system.

In short, the copyright system is broken at a number of levels--compliance costs imposed on both personal and commercial users of copyrighted materials are unjustifiably high; policing costs paid by copyright owners to protect their interests also are quite large; and copying and distribution of protected materials-especially, but not exclusively, digital works--is simple, inexpensive and fast. Extrapolating the model that could have been used to find Sony responsible for the copying by its machines and that has been used to a limited degree to resolve disputes over personal copying in the United States, Israel, Germany and elsewhere, will result in a much more rational copyright system. Doing so requires five steps.

First, and most importantly, we must be willing to rethink the underlying structure of copyright law from top to bottom. Rather than focusing on particular forms of technology, the time has come to pose a new question. Can a statutory scheme be devised encompassing all forms of copying that may be accomplished repetitively and quickly by the use of a machine, device or system, whether by one person or by many people using similar forms of technology in scattered locations? While traditional forms of copyright and remedial structures remain sensible for "old fashioned" forms of unlawful copying such as making one copy of a sculpture by hand or using the blueprints for one building to construct a clone or for large single transactions

\footnotetext{
${ }^{68}$ For more discussion of the ways copyright regimes may reduce the dissemination and use of preexisting works, see Pessach, supra n. 15.
} 
such as such making a movie based on a novel, most other forms of duplication and distribution-reprography, taping, digital file sharing, digital file storage systems, DVD copying and any other form not yet know to us-should be subsumed under a new system.

Second, satisfactory remuneration of copyright owners cannot be extracted from users of copying technology on a use by use basis. The standard system requiring individuals to obtain permission to use copyrighted material and obligating copyright owners to sue infringers case by case must be abandoned as too cumbersome. This is not a new idea. Royalties for performance of compositions, for example, have been paid by establishments and businesses for years into royalty pools run by ASCAP, BMI, SESAC and other performance rights societies. Driven by the same sorts of compliance and policing costs now extant in the digital world, owners and users of musical compositions long ago established royalty pool systems for the performance of such works and sold blanket licenses covering the entire pooled repertoires to radio stations, nightclubs and other enterprises performing music publicly. And the specific statutory provisions recently adopted in the United States, Israel and Germany in the cases of digital audio taping, various forms of video and audio recording, duplication of CDs and use of reprography machines impose levies on both machines and duplication media to fund royalty pools. Such systems should be broadened to encompass all easily repeatable forms of duplication and distribution. ${ }^{69}$

Third, the size of levies imposed on various devices and media cannot be legislatively established. Because of legislative lethargy and log rolling, statutory rates will be revised too infrequently. In addition, legislatures will be slow to respond to new technology and devices as they appear. The new structure should establish an independent rate setting agency, require it to establish appropriate levies for all forms of duplicating devices and the media they use, and allow affected parties to petition the courts to force the agency to impose levies where appropriate. Today that would include cassette tape machines and tapes, video tape machines and tapes, digital recording devices of all sorts, computer servers on networks, network routers and other signal distribution equipment, personal computers, hard drives, flash cards and other digital storage devices, computer diskettes, reprography machines and any other

69 Suggestions to impose levies on duplicating equipment and media are also beginning to appear in the literature. See William W. Fisher III, Promises to Keep: Technology, Law and the Future of Entertainment (Stanford, Stanford University Press, 2004) 199-258. Peer-to-peer copying is the focus of Neil Weinstock Netanel, "Impose a Noncommercial Use Levy to Allow Free Peer-to-Peer File Sharing" (2003) 17 Harv. J.L. \& Tech. 1. Mark A. Lemley and R. Anthony Reese, "Reducing Digital Copyright Infringement Without Restricting Innovation" (2004) 56 Stan. L. Rev. 1345 writes about internet service providers. 
digitally driven printing equipment and the paper they use, CD and DVD recorders and their discs, scanners and any other such devices or media. The agency would also have the responsibility for establishing and maintaining or overseeing the operation by others of appropriate royalty pooling groups, assisting in the establishment of royalty pooling systems not now in existence and overseeing arbitration systems to settle disagreements about the payment and allocation of royalties. ${ }^{70}$

Fourth, litigation against anyone using a device or item of media included in the levy system must be barred. After machines or media are sold and levies paid, copyright obligations will be fulfilled by the purchasers. They may then pursue their creative energies however they wish.

Finally, once the proprietor of a copyrighted work capable of being stored in digital form has relinquished control over the work by allowing any form of distribution that may result in repetitive duplication, the owner must be barred from complaining about the use, storage, duplication or transfer of the work by the use of any levy system device or media unless the moral rights of the proprietor are violated. ${ }^{71}$ Similarly, digital copyright protection systems must be banned. The need for them will disappear once levies are imposed on digital machines and media. ${ }^{72}$

${ }^{70}$ Arbitration systems are used to resolve disputes over the distribution of compulsory royalty pools under existing American law. 17 U.S.C. $\S \S 801-803$. That process appears to be working fine.

71 This may require some alternations in traditional moral right theory. $\$ 12(1)$ of the German Copyright Code, for example, declares it a moral right that the "author shall have the right to determine whether and how his work is to be disseminated." An efficient levy system will require a narrow understanding of the meaning of "dissemination." Copyright codes also commonly provide that owners have the right to "reproduce" or "publish" a work. These ideas may also have to be limited. This issue is discussed in the next section of this paper.

${ }^{72}$ I am certainly not the first person to suggest that a levy system should be implemented, though many of the details presented here are lacking in other literature. See, e.g., Fisher, supra n. 69, at 198-262; Jessica Litman, "Sharing and Stealing" (2004) 27 Hastings Comm. \& Ent. L. J. 1. Others have suggested that establishing free areas on the web may be a way to undermine the traditional market for copyrighted products and force businesses to change their strategies without making significant alterations in the copyright code. Those running the efforts to develop freeware to compete with Microsof-Linux, Mozilla, Firefox and Thunderbird, among others-are attempting this strategy with some success. Scholarly support for this approach is most notable in the work of Lawrence Lessig. See, e.g., Lawrence Lessig, Free Culture (New York, Penguin Press, 2004). Some work is now being released with Creative Commons licenses allowing for free distribution. Ariana Eunjung Cha, "Creative Commons is Rewriting Rules of Copyright" Washington Post, 15 March 2005, E1. And IBM recently made headlines by agreeing to make many of its patents freely available in an effort to stimulate use of its products and enhance its support and consulting business. Steve Lohr, "Sharing the Wealth at IBM" New York Times, 11 April 2005, Cl. Though all of these "open" online community endeavors make lots of sense, I am skeptical that they will so significantly undermine traditional business models seeking to use intellectual property law to protect their interests that a levy system will become unnecessary. 


\section{Objections}

At least three sets of reasonable objections to such reforms may be put forth. Though none present serious impediments to widespread changes in copyright law, each will have to be taken into account in framing new statutory provisions. First, certain inequities may arise in the costs imposed upon consumers in a levy system. Those who complain that allowing copyright owners to create and use digital file protection systems imposes inappropriate costs on the fair use of protected works, may also worry that imposing levies on the sale of machines and media will have a similar impact. And from the opposite direction, those who rarely use machines or media to duplicate or disseminate copyrighted works may object to paying levies on equipment they purchase.

Second, traditional copyright law allows authors to make decisions about the release, publication, dissemination and use of their copyrighted works. Sometimes this realm of control is reposed in simple language providing economic rights to copyright owners - -the right to publish or distribute, for example. The same issue may also surface in moral rights provisions granting authors control over publication or dissemination of a work. In both cases, objections may arise if levy systems and royalty pools reduce the control of authors and copyright proprietors over the use of their works and restrain their ability to control the channels of distribution.

Finally, levy systems create royalty pools from which payments are made to copyright owners. Such pooled royalty payment schemes are always inexact. It is impossible to guarantee that copyright owners will receive payments representing the actual use of their works. Does this mean that the royalty pool idea should be abandoned? Payments may also be skewed if the pooling arrangements are subject to significant amounts of cheating. Dissemination and distribution data for various types of works will have to be monitored in some fashion so that organizations controlling pooled royalties can structure fair and equitable payment systems. Are there problems in monitoring the dissemination and distribution of digital files? Is it possible to avoid privacy intrusions and cheating while still gathering the information necessary to operate pooled royalty systems?

\section{Levy Inequities}

An important reason for opposing the Digital Millennium Copyright Act was its failure to protect the fair use rights of those using protected works. ${ }^{73}$ In the new

${ }^{73}$ See supra n. 46 and accompanying text. 
copyright scheme proposed here, everyone purchasing machines and media would pay levies, including those who use works fairly. That, some might claim, has the effect of nullifying fair use rules. Similarly, those who never use machines or media to duplicate or disseminate protected works also may overpay under a levy system. Individual users of digital machines will pay levies without regard to the probabilities that they will duplicate or distribute copyrighted works.

On one level these objections are obviously valid. Some people who use works fairly or not at all will pay more than under the present system. This iniquity is the most commonly used basis for opposing the generalized use of levy systems. If the primary purpose of a machine is not to copy protected works, they argue, why should levies be imposed $?^{74}$ Such arguments are overstated. A properly structured levy system will operate as a reasonably close approximation of the level of copying each of us undertakes. First, those who rarely copy or distribute digital files will generally purchase a much smaller volume of digital media than those who regularly copy and disseminate files. Second, levies on equipment should vary depending on the duplicating capacity and typical uses of various devices. Levies imposed on many items, especially consumer products often used for legitimate private purposes, should be low relative to the cost of the machine. Charges on equipment capable of large scale duplication-large volume reprography machines used by institutions or high speed network servers and routers, for example-should be significantly higher. Finally, objections by low level users should not be allowed to control the entire structure of copyright law. Even those who never use computers to duplicate or transfer protected works gain the general cultural benefits associated with appropriate incentives for the creation and distribution of the creative works that make life interesting. It is not unfair to ask all those who purchase devices capable of making and distributing copies to pay a share of the social cost of creating incentives for the making of creative works.

Second, and most importantly, there are steps that may be taken to protect fair users. A bit of care must be taken here. In a levy system, it is much more difficult to claim that individuals copying and disseminating digital files are fair users than it is under the present copyright structure. The major concerns about imposing liability directly on consumers in the Sony case revolved around the intrusiveness of enforcement actions. That concern arose only because traditional copyright policing systems rely upon case

\footnotetext{
${ }^{74}$ Hugenholtz, Guibault and van Geffen, supra n. 39, at 40, for example, claim that if "the primary use of certain equipment is not to reproduce protected works, performances or phonograms for private purposes, subjecting such equipment to a levy would not be justified." This led the authors to conclude that computers, for example, should not be levied.
} 
by case litigation to deter misuse. ${ }^{75}$ But if the prospect of litigation is removed, there is no strong policy reason for completely freeing users of digital equipment and media from the obligation to pay into royalty pools through equipment and media levies. The per-use cost to typical consumers will be low and the benefits to users will be significant-no policing and the freedom to browse, download, and surf the web to their hearts' content. Furthermore, to the extent that traditional litigation is brought against users of copyrighted materials, the fair use defense will still be available. If, for example, a newspaper or magazine publishes excerpts from an important chapter of a book prior to its release, the levy system would not bar a law suit. ${ }^{76}$ If the newspaper or magazine has a fair use defense, it can be raised. ${ }^{77}$

One result of moving to the levy system, therefore, is that most important fair use issues relating to digitally distributed or easily duplicatable works become institutional rather than individual. Instead of focusing on the ways each of us makes use of previously created materials, a levy system promotes discussion of the large structures in society that should be accorded privileged copyright positions. One of the core values in the American fair use system, for example, involves recognition of the importance of allowing educational institutions to make use of copyrighted works. While the extent of this privilege has been the subject of eontinuing debate, ${ }^{78} \S 107$ of the copyright code expressly gives a preferred position to duplication of materials for classroom use. Moving to a levy system actually simplifies the implementation of this policy. Rather than dealing with educational fair use on a case-by-case basis-an unwieldy and time-consuming undertaking given the scale of use and the number of institutions- $a$ "fair use" privilege can be extended by reducing the size of the levies that must be paid by educational institutions when they purchase duplication devices

75 The same issue arose in Germany, where the courts declined to impose liability on individual users of recording equipment because of concerns about intrusive policing. Gaita and Christie, supra $\mathrm{n}$. 59 , at $428-29$.

${ }^{76}$ The levy system, remember, kicks into gear only after the publisher relinquishes control over a work.

7 The dispute over publication of material from Ford's memoirs by The Nation is a perfect example. See Harper \& Row, Publishers v. Nation Enterprises, 471 U.S. 539 (1985).

${ }^{78}$ The debate actually began while the Copyright Act of 1976 was being drafted. Disputes over the extent to which educational uses of works should be privileged led to the creation of guidelines that were incorporated into the legislative history of the code. The Agreement on Guidelines for Classroom Copying in Not-For-Profit Educational Institutions with Respect to Books and Periodicals, reprinted in H.R. Conf. Rep. No. 1733, 94th Cong., 2d Sess. (1976). The Guidelines were written jointly by publishers and various educational organizations. But two very important groups-the American Association of University Professors and the Association of American Law Schools-refused to agree to the guidelines. 
and media. ${ }^{79}$ While use of differently sized levies opens the possibility of seepage and corruption, a similar system is widely used throughout the United States. Non-profit institutions of all sorts are frequently exempt from paying sales taxes. Each exempt organization is given a special tax number to use with merchants, who are then freed from the obligation of collecting the tax. Similar systems could easily be implemented to institutionalize fair use, not only for educational institutions but also for any other organizations or individuals Congress wishes to protect.

\section{Dissemination Control Rights}

Successful operation of a levy system requires that users be free to make use of a copyrightable work once control over an easily duplicatable version of it has been relinquished. At least three sets of closely related problems might arise in such a copyright structure. First, once a work has been released into the reproduction world, it may be disseminated by organizations or individuals the copyright owner would normally bar from access. Second, and more importantly, the variety of ways in which digital works may be quickly altered and recast means that some digital distributions may conflict with the creative preferences of both the author and the copyright owner. Finally, many businesses now control access to copyrighted materials and charge for subscriptions, per use activities, or other access to the protected work. How much control should an author or copyright owner have over release of a work into the reproductive world?

For the most part American copyright law gives the owner control over methods of distribution and dissemination. The rights to reproduce, distribute and arrange for the sale of a work are among the exclusive rights held by copyright owners. ${ }^{80}$ Construction of a levy system allowing the digital distribution of all kinds of works is alien to the traditional privileges of copyright ownership. Is there any reason to retain all of the old traditions? No. Indeed implementation of the most traditional policy basis for American copyright law - the desire to maximize distribution of copyrighted works by creating incentives for their creation and distribution-is enhanced by a levy system that limits ownership controls over the dissemination of original works.

Placing control over distribution decisions in the hands of copyright proprietorsthe traditional rule-may restrict rather than enhance distribution of a work in irrational ways. Works may be bottled up, released in small quantities or placed in

${ }^{79}$ This sort of system is a bit like the German provisions mandating "fair" compensation for allowing private persons to make copies of protected works. See supra $\mathrm{n}$. 19.

${ }_{80} 17$ U.S.C. $\$ 106(1)$ and (3). 
highly restricted distribution channels. It may be justifiable to leave decisions about the first dissemination of a work in the hands of the author. ${ }^{81}$ For many creative souls, a crucial part of the process of composing a new artistic work is deciding when the work is finished and what form its release should take. It is difficult if not impossible, for example, to justify a requirement that all painters must release their works for sale whenever a gallery owner declares them "finished." One can even make a strong argument that some authors should be able to retain control over distribution by placing a work in narrow channels. Consider, for example, artists who make only twenty-five copies of an etching or three copies of a photograph. But once a work is voluntarily placed in channels where it may be easily duplicated and distributed, society-given the pervasive presence of duplication technologies-is free to assume that the author or owner is prepared to accept widespread distribution of a work. So, for example, a photographer who sells twenty-five copies of an image might be allowed to bar its digital duplication and distribution. ${ }^{82}$ But once the photographer has placed or allowed someone else to place the image on a website, the levy system should take over. In this setting, restraining distribution of copyrighted products reduces the cultural impact of the work without any countervailing need to protect the creative interests of authors. The American preference for maximizing distribution of such works should then dominate.

This collision in the values of authorial control and distribution certainly is not new to American copyright law. In fact, there are important examples of settings in which control over distribution has been taken away from copyright proprietors. The oldest and most important harks back to piano scrolls and sound recordings. From 1909 until today, anyone may release another mechanical reproduction of a composition after the author agrees to the release of the first recording. Rather than allow one company to

81 There are two very famous examples of this in American copyright law. Salinger v. Random House, Inc., 811 F.2d 90 (2d Cir. 1987) involved the publication of excerpts of letters written by J. D. Salinger. Salinger, who was a recluse. had no desire to publish the letters. In the other case, Harper \& Row, Publishers v. Nation Enterprises, supra n. 77, the Nation published excerpts about the pardoning of Richard Nixon from ex-President Ford's memoirs prior to the book's scheduled release date, preempting an agreement between Time Magazine and Harper \& Row granting Time first publication rights. In both cases, the authors' right to control first publication prevailed.

82 A strong argument may be made that just the release of twenty-five copies should trigger the levy system. Photographs may be scanned quite easily and sent on their digital way. As time goes on, the mere release of a work to another person may come to be read as a general release into the levy system. We may come to the point where royalties for all copyrightable works are governed by the levy system once an author agrees to any distribution of the work. In the case of photography, it also is inevitable that the price for an "original" copy signed and numbered by the photographer will be significantly higher than the levy system costs imposed on users obtaining a copy of the picture online. 
limit the distribution of recordings of popular works by imposing irrational conditions on their sale or limiting production to facilitate monopoly pricing, Congress chose to maximize availability of the work. Similar instincts should guide us once a work has been released in an easily reproducible form, even if that requires significant alterations in the language of the exclusive rights granted to copyright owners in $\$ 106$.

Objections to such changes may be made by a number of major corporate purveyors of online data bases and large aggregations of copyrighted materials, such as Westlaw or Lexis. Why, they will ask, should their ability to limit access to their data bases by requiring the payment of subscription fees be endangered by allowing anyone to use their collections once material has been put online? In fact, their income streams would not be placed at risk. They would just come from a different system. First, such businesses would be free to contract with copyright owners to become the first online purveyor of their works. Presumably these contracts would include provisions about splitting any royalties forthcoming for online use of the materials from the levy system. Second, though subscription fees would be barred in a properly functioning levy system, Westlaw or any other online data base company owning rights in copyrighted works would have the right to claim a significant share of the funds paid to literary work royalty pools from the sale of computers, network equipment, duplicating equipment and media. ${ }^{83}$

The ability to alter digital works presents a more difficult problem, especially in Israel and most civil law countries. While it is justifiable to presume that an author accepts widespread distribution once a work is released in digital form, it is not so easy to conclude that the author also accepts any digital alteration in the work that may occur "downstream." This is so for at least three reasons. First, most distribution is undertaken not by the author but by a publishing house of some sort-book publisher, record company, movie studio or some other business. The contractual arrangements between the author and publisher entail distribution of the work in a certain form and, given a levy system, with an expectation of certain royalty payments from equipment and media used in its distribution. Alteration of the work into a different form is usually not contemplated by such arrangements.

Second, in the copyright law of virtually all nations, control over the use of a work in a subsequent, different creation, is given to copyright owners. In the terms

${ }^{83}$ Virtually identical conclusions should be reached in any country-including Israel and most civil law countries in the world-where the primary purpose of copyright law is to protect the natural rights of authors, rather than, as in the United States, to maximize distribution of creative works. For the right to receive remuneration for creativity is as much a natural right as it is a product of utilitarian theory. The point is nicely made about German law by Gaita and Christie, supra n. 59, at 432-33. 
of the United States' code, they hold the exclusive right to authorize the making of a "derivative work" - one "based upon one or more preexisting works [...] in which [...] [a] work may be recast, transformed, or adapted." ${ }^{84}$ Use of a work in a new form is considered a right separate from control over distribution.

Third, there are some potentially difficult conflicts between traditional notions of moral rights and digital technology. The civil law moral right tradition grants authors a series of protections, even after they have transferred publication, distribution or other economic rights in their copyrighted works. Israel, for example, grants authors the right of attribution as well as control over changes in a work that are "liable to injure its author's honor or reputation." more limited. Since it is subject to contractual waiver by the author, the American copyright code really constructs an economic rather natural law principle of moral rights. In addition, it applies only to works of visual art. ${ }^{86}$ The traditional civil law rule, however, is much broader and based on the theory that certain creative instincts are inherent in the personality of an author and not subject to waiver. Israel, for example, separates moral and economic rights in copyrighted works and bars waiver of moral rights by authors. This strongly suggests that release of a work into a digital stream by an author may not be taken as a waiver of moral claims.

No excuses for diluting traditional rights of attribution are presented by digital technology. It is so simple to retain the author's name on any digitally transferred work that it is hard to imagine an excuse for removing it. The imposition of significant penalties for interfering with attribution is appropriate. ${ }^{87}$ Handling claims of digital alterations beyond authorship in a levy system, however, will require some care. If

8417 U.S.C. $\S \S 101,106(2)$. In many places this issue is subsumed in infringement law. That is, if something labeled a derivative work in American law is made without the permission of the copyright owner in the underlying work, it is deemed to be an infringement. In Israel, the derivative work provision is not as broad as in the United States, applying only to translations, novelizing a dramatic work or dramatizing a novel. Article 1(2), Copyright Act of 1911. But similar protection exists because copyright owners may claim that a derivative work - a play based on a novel for example-copies a portion of and therefore infringes upon the underlying work.

${ }^{85}$ Article 4A, Copyright Ordinance of 1924.

${ }^{86} 17$ U.S.C. $\S 106 \mathrm{~A}$. The definition of a work of visual art in $\S 101$ is complicated. Basically it is a work of fine art or photography released in editions of 200 or less. There is some case law support for the proposition that unfair trade law bars the alteration of a work in ways that endanger the reputation of authors. See Gilliam v. American Broadcasting Companies, Inc., 538 F.2d 14 (2d Cir. 1976), a famous case involving atrocious alterations in Monty Python programs in order to allow time for commercials to be aired by an American television network.

${ }^{87}$ Note that the Israel Supreme Court affirmed a quite large damage award for the failure of Hershel Shanks to attribute authorship of proposed wording to fill in missing segments of the MMT Dead Sea Scroll to Elisha Qimron. The copyright infringement judgment was for 20,000 NIS, but the moral right damage award was 80,000 NIS. 
all modifications of copyrighted works are barred, some of the underlying purposes of a levy system will be undermined. But if all digital modifications are allowed, traditional control over the creation of derivative works and the moral rights of authors will be inappropriately diluted. The relevant interests are best balanced by adopting statutory language similar to that in $\$ 115(2)$ of the American Copyright Code. That section allows minor modification of compositions when "cover" recordings are made of compositions previously released to the public. ${ }^{88}$

Three important issues need to be considered in this area. First, we must recognize that reuse of one digital work by another will often entail some changes. Though digital file sharing transfers the same file from one device to another, the use of the work by a transferee may often result in small but harmless alterations to the work. Someone obtaining a picture, for example, may change its size; a person obtaining a paper may increase the font size to make it easier to read; or a music lover may slightly enhance the bass lines in order to improve the sound heard through small computer speakers. Nothing much is gained by penalizing such behavior. In addition, enforcement of any rules barring such changes would be extremely difficult.

Second, the reformed copyright system must limit such changes to those that do not alter the fundamental character of the original work. This limitation protects the copyright owner's right to license derivative works, as well as the author's moral rights of attribution and integrity. One additional caveat is required. Neither the attribution or integrity rights are damaged in any notable way when a single user changes a work but does not redistribute the work. No harm of note is done either to the copyright owner's economic right to control the making of derivative works or to the author's moral right to protect his honor or reputation. Important grounds for complaint may arise only when the altered work is passed along to others. Finally, those using the work should be barred from seeking protection of their non-fundamental changes as a derivative work. In addition to providing further protection of the economic and moral rights of owners and authors, this limitation reduces the possibility that a digital copier will complicate the royalty distribution system by demanding a slice of the royalty pie.

${ }^{88} \S 115(2)$ provides that a cover recording may alter the original composition by making changes in the arrangement of a composition "to the extent necessary to conform it to the style or manner of interpretation of the performance involved, but the arrangement shall not change the basic melody or fundamental character of the work and shall not be subject to protection as a derivative work." 


\section{Royalty Pooling Problems}

Remuneration of participants in royalty pools will never conform exactly to the actual digital use of the works of each participant. Depending on the nature of the usage surveys undertaken by royalty pooling organizations, the formulae adopted for allocating monetary pies and the systems used to resolve disputes between pooling organizations claiming shares of any particular royalty pool, payments will be more or less close to the exact amount due copyright owners in a system with perfect information about dissemination and duplication. This is an inherent characteristic of royalty pooling and quite similar in character to complaints consumers and users of copyrighted works might make about the propriety of exacting similar equipment and media levies from those with different copying and distribution habits.

The same issues have been around for decades. ASCAP and other performance right collection organizations are constantly presented with royalty allocation problems. ${ }^{89}$ Each organization has worked out a system for determining the number of times a composition has been played and the amount of money that should be paid to the composition's owner. ${ }^{90}$ ASCAP, for example, gathers play lists and logs from television and radio stations, tapes some broadcasts to double-check the accuracy of lists and logs, obtains set lists from promoters of performances, collects printed programs and assembles a variety of other information from its licensees. The very digital technology that should force us to rewrite the copyright laws also provides tools for assembling and tabulating the performance data. No system is perfect, but the end result is a fair and reasonable approximation of the use patterns for various musical compositions. Similar systems can be created for determining rights in any royalty pools that may arise in a new levy regime. Indeed, one would hope that, as with performance rights in musical compositions, multiple, overlapping pooling societies

${ }^{89}$ Performance rights societies have run into serious antitrust problems in the United States. They were charged with price fixing by requiring radio stations, night clubs and other users of compositions to purchase blanket licenses covering all the music in the organizations' repertoires. Use of blanket licenses enhanced the ability of the performance rights organizations to raise prices by removing the ability of individual users to bargain for the right to use specific works. The case against ASCAP was eventually settled. Among other things, the federal district court retained authority to oversee the prices to be charged for blanket licenses and required ASCAP to offer single use as well as blanket licenses. United States v. The American Society of Composers, Authors and Publishers, 1950-51 Trade Cases $\$ 62595$ (1950). These sorts of problems should not arise in a levy system, provided that the levy rates are decided by a government agency.

${ }^{90}$ A good, but simple, explanation of the ASCAP system may be found in Lee Ann Obringer, "How Music Royalties Work" available at http://www.stuffo.com/music-royalties7.htm (Last visited Septenber 2005). ASCAP and BMI do not use the same system. BMI, for example, tends to favor well-established performers a bit more than ASCAP. 
will emerge and compete with each other in order to provide copyright owners with the ability to strategically decide where to place their royalty producing assets.

The inaccuracies inherent in royalty pooling are a small price to pay for the benefits of a levy system. Given the lack of serious protests from members of performance rights societies about the methods used to pay them, it is reasonable to assume that the economic benefits of the levy system-capturing royalties now lost due to the ease of duplication and dissemination, slashing the transaction costs of compliance with copyright laws to zero in many cases, and reducing the policing costs paid by copyright owners-will be vastly greater than the disaffection costs associated with royalty pooling.

Though the models for royalty pooling have been around for quite some time, the creation of a levy system will pose some new and potentially difficult problems. Tracking performance of musical compositions in the United States has been eased by the existence of regulations requiring radio and television stations to maintain logs of their programming choices. Systems to sample television viewing habits have been around for many years in order to provide data for pricing advertisement time. Other use patterns may be discerned by taking surveys or sending monitors to record play lists in night clubs and other performance venues. A levy system, however, will require a different quality and level of monitoring in order to insure that royalty pools are properly operated and paid. Much of the distribution and duplication on the internet cannot be determined by the traditional monitoring techniques used by performance rights societies. Consider the distribution of music online. How can the exchange of digital music files be monitored without invading the privacy of users? Will cheating arise and can it be detected?

Monitoring file dissemination should not be difficult, though a new technological system will have to be installed on the internet and on various duplication devices such as reprography machines. If each work placed in an easily duplicatable form is given a copyright bar code-much like the universal product code now used to monitor the sale of consumer products ${ }^{91}$ - and every machine capable of copying or distributing a copyrighted work is required to have the capacity to read and report its use to a royalty pool organization, ${ }^{92}$ then monitoring the dissemination of copyrighted

${ }^{91}$ Many copyrighted products-books and sound recordings may be the best examples—already have universal product codes. It may be that the copyright monitoring system could simply piggyback onto the existing UPC system.

${ }^{92}$ While it is possible that such devices could be turned off if they are badly designed or easily accessible, the incentives to do so are quite low. Once a machine has been purchased and its levy paid, no further expenses are imposed on the users of the device. They will gain nothing by disabling it. 
works should be possible. While a phase in period will be required to get such a system up and operating, it need not be terribly long since the technology to create the system already exists. For similar reasons, the costs to create the system should be reasonable. ${ }^{93}$

Though the creation of an online and machine based monitoring system is technically and financially feasible, its implementation will present two potentially controversial problems. First, those bent on cheating could create schemes for the rapid and repetitive online swapping of files in order to increase their share of a royalty pool. As the present onslaught of spam and controversies about cheating in clickadvertising systems on web sites reminds us, the best laid plans of internet visionaries may be unscrupulously used. And second, efforts to control such cheating may create privacy problems if the monitoring system routinely compiles data on the computers sending and receiving digital files.

Certain fairly simple preventative measures should be implemented as the pooling arrangements are established. Use of copyright bar codes, for example, makes it easy to compile date and time information for the dissemination and duplication of a work. Sudden spurts in the use of certain bar codes, except when a work is first made available to the public or gains the attention of the public because of a news or other important event, should be presumed suspicious. Royalty pooling organizations should routinely discount such spurts when they calculate royalty payments. Second, many works will be distributed via both traditional brick and mortar sales and online systems. While we should not expect dissemination rates to be the same in both venues, widely different fluctuations in the two rates should raise concern. Markers for these and other warning signals can be placed in the computer systems that receive data on the use of copyright bar codes and analyzed by the staffs of pooling organizations before royalty checks are distributed.

Use of such monitoring systems will not require routine access to the IP addresses of the machines recording the use of any particular copyright bar code. Information about the bar code, date and time of its use and other information necessary to properly determine royalty rates ${ }^{94}$ can be recorded without any notations about the source from which the data came. The crucial question is whether source data should be held in some place in some form in case significant cheating does occur. Some

${ }^{93}$ If complaints about implementation costs become too severe, it certainly would be appropriate for the government to make some monetary contributions. The long-term benefits of the levy system make such a one-time investment worthwhile.

94 Perhaps the most obvious data of this sort is the number of pages copied from a book on a reprography machine. 
will surely argue that specific machine information should be held in a data base out of the control of pooling organizations and inaccessible to the general public in case prosecuting authorities launch investigations of misbehavior. At least at the outset, however, such a system should not be established. Until proven otherwise, we should assume that monitoring of the data for sudden usage spurts, out of kilter distribution patterns and other signs of abuse will curtail the vast bulk of cheating. The creation of a levy system should not establish new fears of privacy invasions-the very concern that led to the flawed result in the Sony case.

\section{Conclusion}

One day it should be possible for a computer user to sit down at her machine, go to any website in the world, download whatever she needs or wants and enjoy the bounty of international culture. The cost? - a nominal charge levied on the computer and duplication media she uses. The efficiencies of such a system are evident and compelling - no litigation, automatic royalty payments to the owners of rights in any work available online, and entrepreneurial freedom to develop any new device without fear of copyright infringement litigation. Such a system is both required by the arrival of the digital age and possible only with the use of digital equipment to store and process the data necessary to make it work. Surely this can be accomplished. 